\title{
STUDY OF ENVIRONMENTAL DATA FROM BRAZILIAN VEHICLE'S SENSORS AND IT CORRELATION WITH THE CLIMATE MAPPING FROM AUTOMATIC METEOROLOGICAL STATIONS
}

\author{
Philippe Cedraz Lopes ${ }^{a, b}$, Juliana Carla Santos da Silva ${ }^{a}$, Lílian Lefol Nani Guarieiro ${ }^{a}$ \\ Davidson Martins Moreira ${ }^{a}$ \\ a Centro Universitário SENAI CIMATEC, Brazil \\ ${ }^{b}$ Ford Motor Company, Product Development Center, Brazil
}

\begin{abstract}
An evolution of smart and connected cars allows the advancement of smart cities and new business models for automakers. The main objective of this article was to understand the capability of Brazilian vehicles to collect meteorological data, through an observational approach of vehicle technologies and an applied study of automatic weather stations. Through this study, it was correlated meteorological variables that are collected by the stations, as well vehicles, in order to evaluate some of their qualitative and quantitative conditions. In this context, it understood the vehicle's advancement as a mobile sensor and the automakers' ability to explore new business models based on weather data from vehicles.
\end{abstract}

Keywords: Automatic Meteorological Stations, Connected Vehicles, Weather Data, Data Mesh

\section{ESTUDO DOS SENSORES DE DADOS AMBIENTAIS EM VEICULOS BRASILEIROS E SUA CORRELAÇÃO COM O MAPEAMENTO CLIMÁTICO DAS ESTAÇÕES METEOROLÓGICAS AUTOMÁTICAS}

\begin{abstract}
Resumo: A evolução dos carros inteligentes e conectados permitem o avanço das cidades inteligentes e novos modelos de negócios para montadoras de veículos. $O$ objetivo central desse artigo foi avaliar a capacidade dos veículos brasileiros para coletar dados climáticos, através de uma abordagem observacional das tecnologias veiculares e um estudo das estações meteorológicas automáticas. Através desse estudo, foram correlacionadas as variáveis climáticas que são coletadas tantos pelas estações quanto pelos automóveis com o intuito de avaliar algumas das suas condições qualitativas e quantitativas. Nesse contexto, compreendeu-se o avanço do veículo como um sensor móvel e a capacidade das montadoras para explorar novos modelos de negócio com bases nos dados climáticos provenientes dos veículos.
\end{abstract}

Palavras-Chave: Estações Meteorológicas Automáticas, Veículos Conectados, Dados Climáticos, Malha de Dados 


\section{INTRODUCTION}

The Internet of Things is based on the integration of a series of connected devices, in some cases, with embedded sensors capable of collecting data in real time. It allows a new approach for complex systems solving and data analysis, for instance, house automation, intelligent traffic management system and environmental monitoring systems [1].

Nowadays, several monitoring devices can be deployed in a large area to collect data in real time according to the needs of the application. New business models have emerged from data monetization of several connected devices [2]. Companies aim to have products and services focused on the consumer, based on a deep analysis of real time information, data mining and cluster analysis, and others. The same strategy can be applied for public departments as well, that aim to collect essential information for a better country management. In the segment of meteorological forecast for instance, one of the key device being used for monitoring Brazilian's climate conditions is the AMS (Automatic Meteorological Stations), which are spread around the country area in order to collect data from several cities and process all information for weather forecast [3].

Furthermore, public departments and private companies are increasingly looking to use data that allows better management of urban mobility, city development planning [4]. These institutions tend to use relevant information from connected platforms as a database to analyze the profile and behavior of people and the urban mobility. For car manufacturers, new business models are being raised from the data monetization of vehicles in the road, as part of the enterprise value strategy. For instance, vehicles are capable to measure several environmental data around its current location for it owns functionality $[5,6,7]$ and these data can be monetized.

Therefore, this study aimed to understood vehicle technologies and their ability to collect environmental data, correlating with data collection methods from Brazilian stationary weather stations. In addition, this research presents the following central question: how can automakers expand the vehicle's usage as an essential element for smart cities when it comes to collecting climate data? The relevance of this research was shown in the exploration of the vehicle's capacity to contribute to the cities development sustainability and the ability to generate new business models that improve national economy and allows incremental business innovation.

\section{METHODOLOGY}

The applied research methodology for the elaboration of this article had an observational goal, since it aimed to make a technical survey of the current sensory capacity of Brazilian vehicles and correlate with the meteorological variables collected from meteorological stations. This methodology was classified according to its nature, approach, objectives and technical procedures, as shown in Figure 1. 
Figure 1. Classification of scientific research methods.

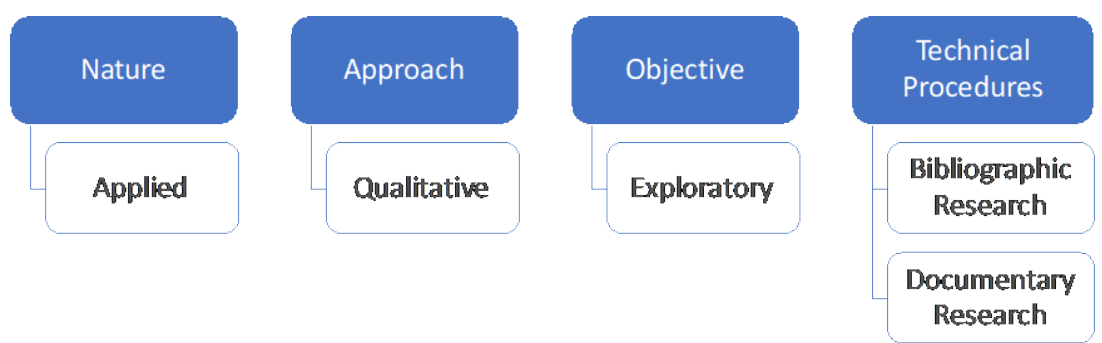

Regarding the nature of the research, it was classified as applied and its approach is qualitative. This type of nature and approach aims at the analysis of a determined segment of study, where the specific and qualitative characteristics of the research are analyzed [8].

In terms of the objective of this research, it has an exploratory character since its main purpose was to deepen the technical-scientific knowledge about a certain area of knowledge and explore existing applications in order to find new central problems, formulate new hypotheses and allow research advance focused on the studied application area [9].

Moreover, with regard to technical procedures, this article used bibliographic research and documentary research [10]. Scientific publications like articles and book chapters were used for reference was mainly obtained from Science Direct, from the last four years of publications, found through the key words: "vehicle as a mobile sensor", "smart cities, "big data and internet of things", "connected vehicles", "intelligent transportations system", "vehicle communications and embedded sensors". Furthermore, formal documents and technical notes published by Brazilian public institutes that had applied meteorological knowledge and automakers organizations was also utilized as base for this research. Therefore, it allowed observational investigation and the functional logical structure of this presented study.

\section{RESULTS AND DISCUSSION}

\subsection{Environmental Sensors in Brazilian Vehicles}

Nowadays, several automakers present a series of vehicle technologies that allow comfort, safety and convenience to improve users experience [5, 6, 7]. Among these, vehicle's sensors are capable to identify rain in the windshield and measure external ambient parameters like temperature, atmospheric pressure, relative humidity of the air, intensity of solar radiation, intensity of external luminosity and link all these variables with the vehicle geolocation, based on the Global Positioning System (GPS). Currently, all of these embedded sensors aim to provide information and data only for the local vehicle application. However, there are limitations of Brazil's current vehicle fleet, since these type of sensors and technology are mostly available on premium catalogues of Small Utility Vehicles (SUV), Pick-ups, Sedan and Sport automobiles, as part of a comfort and convenience accessory, which is not available on entry catalogues or low cost vehicles, [5, 6, 7].

Rain sensors use the principle of reflection of the windshield, to identify in some levels, rain intensities, allowing the automatic activation of the windshield wipers with variable speed [11]. The outside air temperature (OAT) sensor, relative humidity and 
solar radiation are used on the air conditioning controls and it transfer function, in order to adjust the temperature of the internal compartment $[11,12]$. The main objective of measuring the intensity of external light (from the environment and other vehicles) is to automatically activate the headlights and adjust the direction of the light projection, being an item of convenience and safety for the driver. Since all the sensors are designed for automotive applications, they have high reliability and operating precision.

These vehicle sensors that monitor external vehicle variables, enables the vehicle perspective as a mobile data collection unit that has high territorial coverage. Complementary to the sensing system, automakers started to introduce embedded modems in their vehicles, allowing connectivity to external servers (through Wi-Fi and 3G / 4G connection) and leveraging the ability of smart cars to transmit high precision data in real time [13]. The transmission can happen in real time, or it can be scheduled for specific times.

\subsection{Connected Vehicles Capacity}

Vehicles are being designed with the ability to connect to the internet and have a series of data being transmitted to major automakers severs. From the point where vehicles move constantly in large urban centers, automakers are now expanding their perspective to see vehicles not only as a mobility mechanism, but also as a way of obtaining data from users and cities [13].

Furthermore, vehicles are now being considered as connected mobile sensors, capable of extending the power of smart cities by mapping data around an entire city. Data such as: car flow and schedules, climatic conditions and pollutant status can be easily obtained in an entire urban area from connected cars, through several communication strategies, like V2I (Vehicle To Infrastructure), V2V (Vehicle To Vehicle), V2P (Vehicle to People), V2N (Vehicle To Network), among others [14]. Therefore, vehicle as mobile sensors distributed in cities will assist the expansion of smart cities, forming a heterogeneous system capable of collecting various information from large urban centers. The expansion of the user experience and automotive technologies allow automakers to innovate to explore new business models in view of the availability of data.

\subsection{Automatic Meteorological Stations}

Nowadays, the most traditional method of collecting weather data is through AMS, which are distributed throughout Brazil, as shown on Figure 2. According to the Brazilian National Meteorological Institute (Instituto Nacional de Meteorologia INMET), this system is responsible for collecting information such as temperature, humidity, atmospheric pressure, precipitation, wind direction and speed and solar radiation, every minute, regarding the area in which they are located [3]. Every hour this information is compiled and structures, so that it can then be sent to INMET headquarters, where it will be validated and then stored in a database.

In addition, these stations are composed of four subsystems: data collection, data storage, energy and communication. The data collection subsystem is a network of sensors equipped to measure certain meteorological parameter. Stations that are not fully automated, manual sensors can be installed, in order to measure additional 
variables such as total cloudiness, cloud height, cloud base height and horizontal visibility [3].

Moreover, the collected data is recorded in the storage subsystem, using a lowpower processor. These values are stored in a memory unit, for a predetermined time. The power subsystem is equipped with photovoltaic panel modules, and is responsible for supplying the necessary energy for the operation of the station's instruments, making it independent of external electrical energy [3]. Finally, the communication subsystem transmits the information registered at the AMS to INMET's headquarters, via satellite, or cell phone networks. The transmission can happen in real time, or it can be scheduled for specific times.

Figure 2. Example of an Automatic Meteorological Stations (left) and distribution of automatic weather stations across Brazilian territory (right) $[3,15]$.

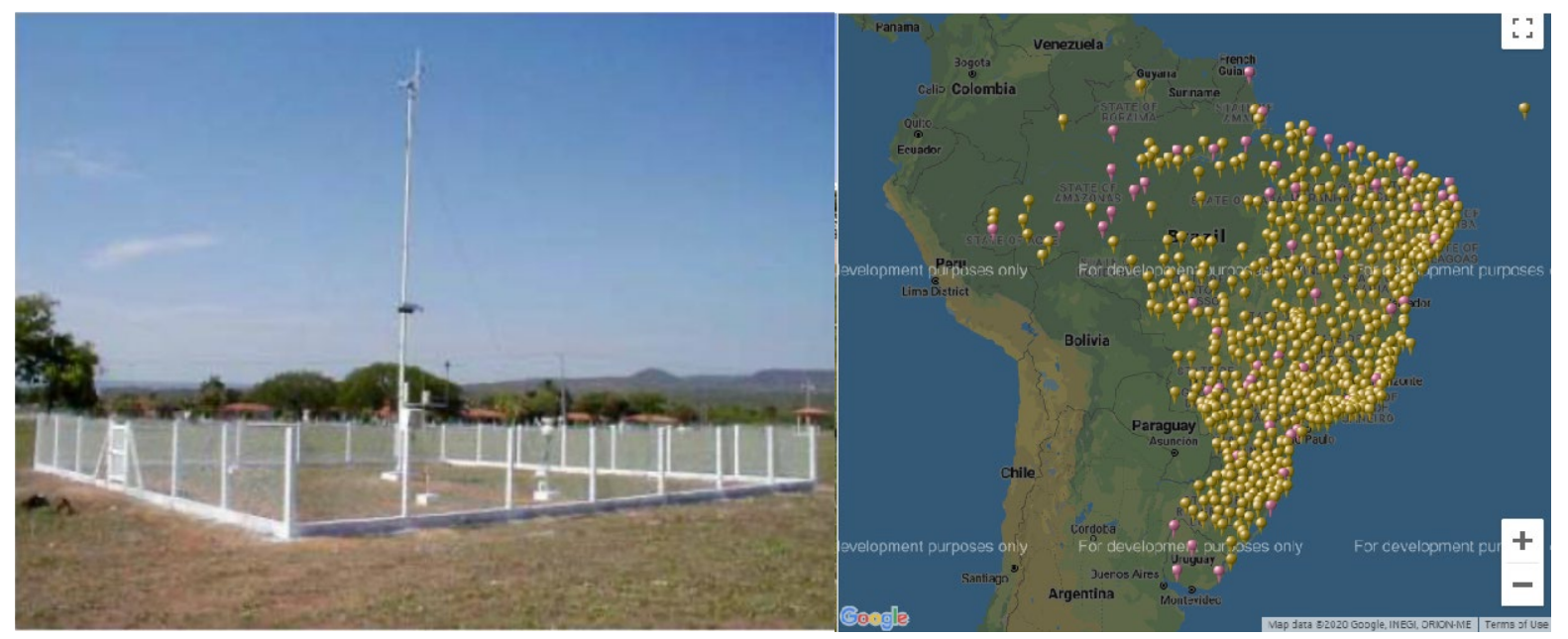

\subsection{Correlation Between Automatic Meteorological Stations and Smart Vehicles}

In the Brazilian scenario, the estimate for the fleet of conventional automobiles and medium and large commercial pick-ups is approximately 43.2 million spread across the national territory. Approximately 2.8 million new cars were produced in 2019 and this number grows year by year, according to the National Association of Vehicle Manufacturers (Associação Nacional dos Fabricantes de Veículos Automotores ANFAVEA) [16]. The number of automatic and conventional meteorological stations in the Brazilian territory registered by INMET are in totals 775 , which represents $0.028 \%$ of the number of cars produced only in 2019. Thus, in a quantitative analysis, it is possible to understand the dispersion dimension of the vehicles compared to the number of meteorological stations in the Brazilian territory.

Regarding the variables of the data obtained, AMS have a data collection subsystem capable of measuring at least 18 meteorological parameters [3], distributed in 8 different categories of information, as shown on Table 1. Through a comparison analysis with current vehicle's subsystem, conventional automobiles do not have the ability to measure seven meteorological parameters, related to the dew point temperatures; speed, direction and wind intensity; and also the rainfall volume accumulated in the period. Therefore, AMS have a greater capacity to collect meteorological data in comparison to smart vehicles. 
In terms of expansion of the sensing subsystem, AMS platforms are modular and allow the addition of new sensors at any station, depending on the need identified by the stakeholders involved [3]. On the other hand, automakers can add new sensors to their vehicles by launching new models, through technical and economic feasibility. The adaptation period of both platforms was not analyzed in this study.

Table 1. Comparison between meteorological variables that can be obtained from weather stations and vehicles $[3,5,11,12]$.

\begin{tabular}{|c|c|c|c|}
\hline $\begin{array}{l}\text { Climate } \\
\text { Variable } \\
\text { Category }\end{array}$ & Specific Climate Variable Description & $\begin{array}{c}\text { AMS' } \\
\text { Measurement } \\
\text { Capability }\end{array}$ & $\begin{array}{c}\text { Vehicle's } \\
\text { Measurement } \\
\text { Capability }\end{array}$ \\
\hline \multirow{3}{*}{ Temperature } & Current Air Temperature $\left({ }^{\circ} \mathrm{C}\right)$ & $X$ & \multirow{3}{*}{$\begin{array}{l}\text { Real Time } \\
\text { Temperature }\end{array}$} \\
\hline & Maximum Air Temperature $\left({ }^{\circ} \mathrm{C}\right)$ & $X$ & \\
\hline & Minimum Air Temperature $\left({ }^{\circ} \mathrm{C}\right)$ & $X$ & \\
\hline \multirow{3}{*}{ Humidity } & Current Relative Air Humidity (\%) & $X$ & \multirow{3}{*}{$\begin{array}{l}\text { Real Time } \\
\text { Humidity }\end{array}$} \\
\hline & Maximum Relative Air Humidity (\%) & $X$ & \\
\hline & Minimum Relative Air Humidity (\%) & $X$ & \\
\hline \multirow{3}{*}{ Dew Point } & Current Dew Point Temperature $\left({ }^{\circ} \mathrm{C}\right)$ & $X$ & \multirow{6}{*}{$\begin{array}{l}\text { Real Time } \\
\text { Atmospheric } \\
\text { Pressure }\end{array}$} \\
\hline & Maximum Dew Point Temperature $\left({ }^{\circ} \mathrm{C}\right)$ & $X$ & \\
\hline & Minimum Dew Point Temperature $\left({ }^{\circ} \mathrm{C}\right)$ & $\mathrm{X}$ & \\
\hline \multirow{3}{*}{$\begin{array}{c}\text { Atmospheric } \\
\text { Pressure }\end{array}$} & Current Atmospheric Air Pressure (hPa) & $\mathrm{X}$ & \\
\hline & Maximum Atmospheric Air Pressure (hPa) & $\mathrm{X}$ & \\
\hline & Minimum Atmospheric Air Pressure (hPa) & $X$ & \\
\hline \multirow{3}{*}{ Wind } & Current Wind Speed (m/s) & $X$ & \\
\hline & Wind Direction $\left({ }^{\circ}\right)$ & $\mathrm{X}$ & \\
\hline & Wind Gust Intensity (km/h) & $\mathrm{X}$ & \\
\hline Radiation & Solar Radiation $\left(\mathrm{kJm}{ }^{2}\right)(\mathrm{W})$ & $\mathrm{X}$ & $X$ \\
\hline \multirow{2}{*}{ Rain Level } & Accumulated Precipitation in the Period ( $\mathrm{mm}$ ) & $X$ & \\
\hline & Relative Rain Intensity Level & $X$ & $X$ \\
\hline \multirow{3}{*}{$\begin{array}{c}\text { GPS } \\
\text { Coordinate }\end{array}$} & Latitude & $\mathrm{X}$ & $X$ \\
\hline & Longitude & $X$ & $X$ \\
\hline & Altitude (m) & $X$ & $\mathrm{X}$ \\
\hline \multirow{2}{*}{ Time } & Collection Date [day/month/year] & $\mathrm{X}$ & $X$ \\
\hline & Collection Time [hour/minute/second] & $X$ & $X$ \\
\hline
\end{tabular}

AMS - Automatic Meteorological Stations.

\section{CONCLUSION}

In this article, it was analyzed the sensorial capacity of conventional Brazilian automobiles for the collection of meteorological data and their connectivity subsystem. The theoretical foundation addressed allowed us to understand which variables can be collected from vehicles and analyze how the automakers can connect this real-time information through a data grid. In parallel, a study was carried out on the AMS, also addressing the capacity of its data collection subsystem. The main objective was to carry out a comparative analysis of the sensory capacity between Brazilian vehicles 
and AMS, aiming to demonstrate the capacity of the automakers as a new way of collecting meteorological data.

As presented in chapter 3.4, Brazilian vehicles analyzed are capable of collecting 11 meteorological parameters, while AMS currently collect 18 variables, which make automobiles a high potential mobile device for relevant data collection. In parallel, with the connectivity power established by the automakers in recent years, automobiles gain the ability to transmit data and reach a territorial coverage superior to AMS, thus increasing the density of the collected data and the granularity of information.

However, in order to leverage the automaker's enterprise value as data providers, it is necessary investments on the creation of private digital platforms and data sharing. Once the automakers analyze the reliability of the mesh data and understand the real needs of meteorological institutes, public departments and other private companies, new business models will be able to adapt, allowing for the monetization of data and technological-scientific advancement. As suggestions for future researches, it is proposed to study monetization strategies existing in the Brazilian market, based on the survey of companies that use meteorological data, a deep analysis of private data sharing based on Brazilian legal requirements and also an applied study of advances in mathematical models linked to weather forecasting based on the massive availability of vehicle data.

\section{REFERENCES}

1 KNIEPS, Günter. Internet of Things, big data and the economics of networked vehicles. Telecommunications Policy, v. 43, n. 2, p. 171-181, 2019.

2 TENG, Haojun et al. A novel code data dissemination scheme for Internet of Things through mobile vehicle of smart cities. Future Generation Computer Systems, v. 94, p. 351-367, 2019.

${ }^{3}$ BRASIL. Ministério da Agricultura, Pecuária e Abastecimento. Instituto Nacional de Meteorologia. NOTA TÉCNICA No. 001/2011/SEGER/LAIME/CSC/INMET. Rede de Estações Meteorológicas Automáticas do INMET, 2011.

${ }^{4}$ KIM, Tai-hoon; RAMOS, Carlos; MOHAMMED, Sabah. Smart City and IoT. Future Generation Computer Systems, v. 76, p. 159-162, 2017.

${ }^{5}$ FORD BRASIL. Suvs e Crossovers Tecnologia - Sensor De Chuva. Available at: <https://www.ford.com.br/suvs-e-crossovers/ecosport/tecnologia/>. Access by: 01 Jun 2020.

${ }^{6}$ VOLKSVAGEM. Características Técnicas dos Catálogos do Modelo T-Cross. Available at: <https://www.vw.com.br/pt/carros/t-cross.html/t-cross-comfortline?--- 
$=\% 7 \mathrm{~B} \% 22$ carros_t -

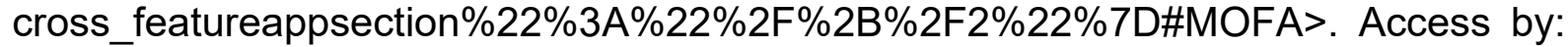
09 Sep 2020.

7 CHEVROLET. Tecnologias de Conforto do Modelo Tracker. Available at: <https://www.chevrolet.com.br/suvs/novo-tracker>. Access by: 09 Sep 2020.

${ }^{8} \mathrm{GIL}$, A. C. Métodos e técnicas de pesquisa social, Atlas, 5a Edição, 1999.

${ }^{9}$ LAKATOS, E. M.; MARCONI, M. A. Técnicas de pesquisa: Planejamento e execução de pesquisas, elaboração, análise e interpretação dos dados, São Paulo: Atlas, 7a edição, 2008.

10 SEVERINO, A. J. Metodologia do Trabalho Científico, São Paulo: Cortez, $21^{a}$ edição, 2000.

11 HELLA. Product - Sensors - Rain/Light/Climate Sensor. Available at: $<$ https://www.hella.com/microsite-electronics/en/Rain-light-climate-sensor-143.html>. Access by: 01 Jun 2020.

12 ALPHENOL. Thermometrics Sensor Assemblies (GE-1923) Outside Air Temperature Sensor (OAT). Available at: <https://www.amphenolsensors.com/en/thermometrics/assemblies/3323-ge-1923>. Access by: 01 Jun 2020.

${ }^{13}$ ABDELHAMID, Sherin; HASSANEIN, Hossam S.; TAKAHARA, Glen. Vehicle as a mobile sensor. Procedia Computer Science, v. 34, p. 286-295, 2014.

${ }^{14}$ DEY, Kakan Chandra et al. Vehicle-to-vehicle (V2V) and vehicle-to-infrastructure (V2I) communication in a heterogeneous wireless network-Performance evaluation. Transportation Research Part C: Emerging Technologies, v. 68, p. 168-184, 2016.

${ }^{15}$ BRASIL. Ministério da Agricultura, Pecuária e Abastecimento. Instituto Nacional de Meteorologia. Estação Meteorológica de Observação de Superfície Automática. Available at: <http://www.inmet.gov.br/portal/index.php?r=estacoes/estacoesAutomaticas>. Access by: 20 Jul 2020.

${ }^{16}$ ASSOCIAÇÃO NACIONAL DOS FABRICANTES DE VEÍCULOS AUTOMOTORES. Anuário da Indústria Automobilística Brasileira 2020, São Paulo, 2020. 